\title{
Sulfur speciation in heavy petroleums: Information from X-ray absorption near-edge structure
}

\author{
Geoffrey S. Waldo, ${ }^{1}$ Robert M. K. Carlson, ${ }^{2}$ J. Michael Moldowan, ${ }^{2}$ \\ KenNeti E. Peters, ${ }^{2}$ and JAMES E. PENNER-HaiIN ${ }^{1, *}$ \\ 'Department of Chemistry, University of Michigan, Ann Arbor, MI 48 109-1055, USA \\ ${ }^{2}$ Chevron Oil Field Research Company, PO Box 1627, Richmond, CA 94802-0627, USA
}

(Received May 31, 1990; accepted in revised form December 10, 1990)

\begin{abstract}
The chemical speciation of sulfur in heavy petroleums, petroleum source rock extracts, and source rock pyrolysis products was studied using X-ray absorption near-edge structure (XANES) spectroscopy. The good energy resolution (ca. $0.5 \mathrm{eV}$ ) at the sulfur $\mathrm{K}$ edge and the strong dependence of XANES on the sulfur environment combine to give excellent sensitivity to changes in the electronic and structural environment of the sulfur. This has permitted identification and approximate quantitation of different classes of sulfur-containing compounds (e.g., sulfur, sulfides (including disulfides and polysulfides as a group), thiophenes, sulfoxides, sulfones, sulfinic acids, sulfonic acids, and sulfate) in a series of petroleums and petroleum source rocks. Our results indicate that the sulfur speciation of geological samples can be correlated with differences in source depositional environment, thermal maturity, and aromaticity. We report organosulfur compositions for the asphaltene, maltene, and liquid chromatographic fractions of two sulfur-rich oils. In addition, we find that the organosulfur species in some, but not all, oils are subject to oxidation upon storage and thus may also be susceptible to oxidation in shallow reservoirs exposed to oxic waters. This work illustrates the utility of XANES as a direct spectroscopic probe for the quantitative determination of sulfur species in geological samples.
\end{abstract}

\section{INTRODUCTION}

NEXT TO CARBON AND hydrogen, sulfur is the most abundant chemical element in petroleum, occuring at concentrations of over $10 \mathrm{wt} \%$ in some heavy oils (HUNT, 1979; TISSOT and Welte, 1984; ORR and SINNINGHE DAMSTE, 1990). Increased use of sulfur-rich petroleums and increased appreciation of the environmental impact of sulfur combustion products have led to a growing interest in understanding the chemical nature of the sulfur in oil and oil precursors (SINNINGHE DAMSTE et al., 1988a, and refs. therein). The present work describes the use of sulfur X-ray absorption spectroscopy for determining the speciation of sulfur compounds in petroleums. This contributes to petroleum geochemistry, has potential utility in predicting the geological distribution of oils with high or low sulfur contents, and also has important implications for enhanced oil recovery and refining operations involving sulfur-rich petroleums.

A graph of frequency vs. sulfur content for a large collection of crude oils shows a bimodal distribution (TISsOT and WELTE, 1984). This distribution is used to classify "highsulfur" (greater than $1.0 \mathrm{wt} \%$ sulfur) and "low-sulfur" (less than $1.0 \mathrm{wt} \%$ sulfur) oils. The total sulfur concentration of many oils correlates with various other properties, including specific gravity, viscosity, and aromatic hydrocarbon content (GRANSCH and POSTHUMA, 1974; ORR, 1986). However, beyond such phenomenological correlations, the role of sulfur in the geochemical transformations which give rise to petroleum is a current geochemical concern. There is a need for better characterization of the abundance and distribution of

* Author to whom correspondence should be addressed. sulfur species in, for example, kerogens, asphaltenes, and highmolecular weight fractions.

Several factors are generally believed to affect the concentration of sulfur in oil. Among these are source characteristics (marine vs. terrestrial), presence or absence of dissolved sulfate, depositional environment (carbonate vs. clastic sequences) (TISSOT, 1981; VAlitov, 1983; Hughes, 1984; TANNENBAUM and AIZENSHTAT, 1985), thermal maturity (Ho et al., 1974; ORR, 1986; SHOU and MYHR, 1988), thermochemical sulfate reduction (ORR, 1974; KROUSE et al., 1988; SASSEN, 1988), and the extent of biodegradation (MAGOON and ISAACS, 1983). Furthermore, the precise mode of sulfur incorporation in source organic matter, i.e., via $\mathrm{H}_{2} \mathrm{~S}$ attack at susceptible centers (CASAGRANDE et al., 1979; MANGO, 1983; SINNINGHE DAMSTÉ et al., 1989b,c), or mechanisms involving elemental sulfur or polysulfides (DOUGLAS and MAIR, 1965; MARTIN and HODGSON, 1973; DE RoO and HodGSON, 1978; CASAGRANDE and NG, 1979; AIZENSHTAT et al., 1983; PrzeWOCKI et al., 1984; WhITE et al., 1988; KoHNEN et al., 1989) remains an active area of inquiry. It is clear that both $\mathrm{H}_{2} \mathrm{~S}$ and polysulfide can react with functionalities such as double bonds during very early diagenesis (SINNINGHE DAMSTE et al., 1989c; KOHNEN et al., $1990 \mathrm{a}, \mathrm{b})$. The finding that sulfur compounds in the asphaltenes and various chromatographic fractions of oils have uniform $\delta^{34} \mathrm{~S}$ isotopic compositions (THODE and MONSTER, 1970 ) suggests that the sulfur in each of the fractions comes from sulfur species with identical sulfur isotopic compositions.

Chemical characterization is essential both for general understanding of organosulfur transformations associated with petroleum formation and alteration, and for the development of organosulfur biological markers (SINNINGHE DAMSTE et 
al., 1989b). Unfortunately, chemical characterization of sulfur-containing compounds in heavy oils, asphaltenes, sourcerock bitumens, and kerogens is difficult. There is no generally applicable analytical method that is capable of non-destructive chemical analysis for sulfur. Previous studies of sulfur composition in geochemical samples have utilized chemical methods, including Raney nickel desulfurization (MAJCHROWIEZ et al., 1987; SCHMID, 1986; SINNINGHE DAMSTÉ et al., 1988b, 1990; DE LEEUW and SINNINGHE DAMSTE, 1990), pyrolysis in combination with chromatography and mass spectroscopy (SinNinghe DAmSTÉ et al., 1989a; PHILP et al., 1988; PAyzant et al., 1988; Eglinton, et al., 1990), or chromatographic (SINNINGHE DAMSTE el al., 1988a; REYNOLDS and BIGGS, 1988) methods to identify sulfur-bearing components. Chemical methods are relatively insensitive, and both chemical and pyrolytic methods are subject to possible artifact formation; organosulfur compounds in heavy oils have long been known to include thermally unstable species (ColEMAN et al., 1953). Chromatographic methods give more precise chemical identification (VALISOLALAO et al., 1984; SCHMID et al., 1987; SINNINGHE DAMSTÉ et al., 1986, 1987, 1988a, 1989b; PAYZANT et al., 1983, 1989), showing the presence of thiolanes, thianes, and cyclic terpenoid sulfides in oils (ORR and SINNINGHE DAMSTE, 1990). They are generally limited to compounds having relatively low molecular weights, although thiophenes containing up to 54 carbons have been identificd (KOHNEN et al., 1990a). Chromatographic methods can require pre-processing (e.g., SINNINGHE DAMSTÉ et al., 1988b), which can alter the nature of the compounds being studied and which also prevents analysis of insoluble materials (e.g., kerogens, insoluble bitumens, etc.). Most importantly, both chemical and chromatographic methods have limited utility in studies of high molecular weight asphaltene components.

Spectroscopic methods avoid many of these problems; however, traditional spectroscopic methods (e.g., UV-visible, IR, EPR, NMR) find limited application for sulfur containing compounds. In contrast, X-ray absorption near-edge structure (XANES) spectroscopy is quite useful for studies of local atomic environments (see BART, 1986, for a review). XANES refers to the structured absorption occuring within ca. $50 \mathrm{eV}$ of the absorption threshold of an element. A typical sulfur XANES spectrum consists of an intense, narrow absorption peak (the so-called "white-line") superimposed on a more or less structured absorption discontinuity. The sensitivity of XANES spectra to the electronic structure, oxidation state, and geometry of the absorbing site is well known. This sensitivity is particularly pronounced for low energy (2-3 keV) edges, since these have significantly better energy resolution (KRAUSE and OLIVER, 1979; HeDMAN et al., 1986; FRANK et al., 1987) than is possible at higher energies. TYSON et al. (1989) have made use of this high energy resolution in a recent study of sulfur electronic structure using angle resolved XANES spectroscopy. In addition to XANES, two related core-electron spectroscopies have been proposed for sulfur analysis. X-ray photoelectron spectroscopy has been used to characterize the sulfur in asphaltenes, kerogens, and bitumens (Ruiz et al., 1982; ClARK et al., 1983; CLARK and WILSON, 1984); however, this technique is sensitive exclusively to spe- cies on the surface and is thus difficult to apply in bulk studies. A second alternative, in which energy-resolved X-ray fluorescence is measured in place of $\mathrm{X}$-ray absorption, has also been proposed as a method for determining sulfur composition in fossil fuels (ANDERMANN et al., 1987). This method has not been widely used.

SPIRO et al. (1984) used XANES to characterize the sulfur speciation in coal and related samples. HUFFMAN et al. (1987, 1988,1989 ) extended this to include both identification and structural characterization of sulfur species in coal using extended X-ray absorption fine structure. In these studies, the emphasis was on qualitative rather than quantitative characterization of the sulfur species. Recently, GEORGE and GORBATY (1989) used XANES to investigate sulfur speciation in asphaltenes. They made use of third derivative spectra to improve the resolution of the spectroscopic features from different sulfur species. Although this permitted qualitative identification of the sulfur species present in their samples, they concluded that quantitative analysis was difficult. This is due both to the intrinsic difficulties of quantitating third derivative spectra and to the potential effects of "self-absorption" (see below). We have applied the XANES technique to petroleums and petroleum source-rock pyrolysis products. In contrast to previous work, which was limited to qualitative identification of different sulfur-containing species in a sample, we have developed a method for quantitating different sulfur-containing species in a sample.

\section{EXPERIMENTAL}

\section{Sample Preparation}

Model compounds studied included elemental sulfur (Fisher), benzyl disulfide (Aldrich), benzyl sulfide (Aldrich), $d l$-methionine (Aldrich), l-cysteine (Alfa), 2-hexadecyl thiophene (Kodak), benzyl sulfoxide (Aldrich), phenyl sulfoxide (Aldrich), dibenzothiophene sulfone (Aldrich), phenyl sulfone (Aldrich), cysteic acid (Alfa), and sodium sulfate (Mallinckrodt). All models were purchased from the indicated source and used without further purification. Model compounds were examined as dilute (ca. $0.33 \mathrm{wt} \%$ sulfur) solutions to minimize the effects of self-absorption. The $d l$-methionine and $l$ cysteine were examined as aqueous solutions, benzyl sulfoxide and dibenzothiophene sulfone were diluted in dimethyl formamide (DMF), and the other models were diluted in o-xylene. Cysteic acid, $l$-cysteine, $d l$-methionine, sodium sulfate, and benzyl disulfide were also examined as neat solids, in order to determine the effect of the solvent on the electronic environment of the central sulfur. Solid samples were ground to finer than 600 mesh and dispersed thinly on Mylar tape containing a sulfur-free adhesive and mounted over the window of an aluminum plate. Viscous fluid samples were applied as a thin film on Mylar and treated in the same manner as the models. Solutions were placed in cells equipped with $6 \mu \mathrm{m}$ polypropylene windows. Aqueous sodium sulfate solutions $(0.1$ to $1.0 \mathrm{M})$ and oxylene solutions ( 0.3 to $3.0 \mathrm{wt} \%$ sulfur) of a high-sulfur marine oil ( 8.0 wt $\%$ sulfur) were studied to determine the accuracy of the self-absorption correction techniques.

\section{Sulfur Analyses}

Total sulfur content was determined by combustion using a LECO Model SC132 sulfur analyzer.

\section{Asphaltene Precipitation}

Asphaltene/maltene fractionation was pertormed on Rozel Point heavy oil, Sample No. 15; Utah, Monterey heavy oil, Sample No. 1; 
California and Uinta Basin oil, Sample No. 18. Oil samples were diluted $50 / 50$ (weight:weight) with toluene, and $10.0 \mathrm{~g}$ of the solution were poured into $400 \mathrm{~mL}$ of $n$-pentane. The flask containing the mixture was shaken for two minutes, wrapped in aluminum foil to exclude light, and allowed to stand undisturbed at room temperature for $24 \mathrm{~h}$ to permit asphaltene precipitation (SPEIGHT, 1980). After $24 \mathrm{~h}$, the $n$-pentane supernatant was carefully removed, filtered ( 3 micron fluoropore [Millipore]), volume reduced under reduced pressure, and evaporated to constant weight in a stream of dry $\mathrm{N}_{2}\left(57^{\circ} \mathrm{C}\right)$ to provide the maltene fraction. The precipitant was evaporated to constant weight under reduced pressure to provide the asphaltene fraction. All solvents were Burdick and Jackson HPLC grade.

\section{Maltene Liquid Chromatographic Fractionation}

Isolated maltenes for each oil (Samples 1, 15, and 18) were separated into polar, aromatic, and saturated hydrocarbon fractions by a twostep procedure. $100 \mathrm{mg}$ of maltene were dissolved in $6 \mathrm{~mL}$ of $n$ hexane and applied to a $n$-hexane-washed silica gel in a standard Sep-Pak® cartridge (Millipore). The cartridge was first eluted with $n$-hexane $(10 \mathrm{~mL})$, to give combined saturated and aromatic hydrocarbon fractions, and subsequently eluted with methanol $(3 \mathrm{~mL})$ and dichloromethane $(10 \mathrm{~mL})$, to give the polar fraction. The saturated and aromatic hydrocarbon fractions were evaporated under dry $\mathrm{N}_{2}$ at $40^{\circ} \mathrm{C}$ to $2.5 \mathrm{~mL}$ and further fractionated by HPLC using a $50 \mathrm{~cm}$ $\times 9.4 \mathrm{~mm}$ I.D. silica gel ( 10 micron) column (Whatman Magnum 9), Waters Model M6000 HPLC pump, Model 440 ultraviolet (UV) absorbance detector, Model 401 differential refractometer (RI), and Rheodyne Model 7125 injector. After sample injection, $n$-hexane mobile phase $(2.00 \mathrm{~mL} / \mathrm{min})$ eluted the saturated hydrocarbons between 11.0 and $14.2 \mathrm{~min}$. The aromatic hydrocarbons were subsequently backflushed from the column. The saturated hydrocarbon, aromatic hydrocarbon, and polar (resinous) fractions were each evaporated to constant weight under dry $\mathrm{N}_{2}$ at $40^{\circ} \mathrm{C}$. The saturated hydrocarbon fractions were too small for sulfur XANES analyses.

\section{Hydrous Pyrolysis}

Hydrous pyrolysis is a technique to simulate petroleum generation under controlled conditions in the laboratory (LEWAN, 1985; PETERS et al., 1990). About $400 \mathrm{~g}$ of presieved, homogenized rock chips, ranging in size from 0.5 to $1.0 \mathrm{~cm}$, were loaded into a 1-L stainless steel reactor vessel (Parr Instruments, Inc.). Distilled water was added to cover the rock chips, yielding a rock to water ratio of $1.5: 1$ by weight. Prior to pyrolysis, the vessel was checked for leaks under $1500 \mathrm{psi}$ of helium and purged three times with helium to remove air. The final helium gas pressure was reduced to 100 psi. Sealed vessels were heated isothermally for $72 \mathrm{~h}$ at either 300 or $360^{\circ} \mathrm{C}$. Following hydrous pyrolysis, expelled oil was collected using procedures similar to published methods (LEWAN, 1985). Hydrous pyrolysis experiments were performed on core material from the Siliceous (5419-5425 ft) and Phosphatic (5649-5655 ft) members of the Monterey formation in the Bradley Lands No. 5-74 well (S5-9N$33 W)$ from the Santa Maria Valley area of Santa Barbara County, California (PETERS et al., 1990). The cores were crushed and the 0.5$1.0 \mathrm{~cm}$ fraction was retained. Prior to the hydrous pyrolysis experiments, indigenous bitumen was extracted from these chips over a period of four months using a large glass column through which reagent-grade methylene chloride was circulated.

\section{Biological Marker Analyses}

Biological marker (monoaromatic to triaromatic steroid hydrocarbon ratio) measurements involved HPLC fractionation of crude

† These energy assignments differ by $2.2 \mathrm{eV}$ from those of GEORGE and GORBATY (1989). This reflects the lack of an absolute energy standard for X-ray spectroscopy but has no effect on the subsequent analysis, which depends only on relative energy assignments. oils and GC-MS analyses of HPLC fractions, and are described elsewhere (MOLDOWAN et al., 1989).

\section{X-ray Absorption Spectroscopy}

Most sulfur K edge XANES spectra were measured at the Stanford Synchrotron Radiation Laboratory (SSRL) using an 8-pole wiggler under unfocused conditions with a $\mathrm{Si}(111)$ double-crystal monochromator. (For a discussion of synchrotron radiation properties, see WINICK and DONIACH, 1980.) The sulfate dilution studies used a bending magnet beamline. Some of the petroleum XANES data were measured using the SSRL 54-pole wiggler in undulator mode, with a Pt-coated focusing mirror and a $\mathrm{Ge}(111)$ double-crystal monochromator. The benefits of this setup for low-Z studies are described elsewhere (HEDMAN et al., 1986).

The monochromator was detuned by about $30 \%$ (undulator) and $70-80 \%$ (wiggler and bending magnet) to eliminate higher harmonic components in the X-ray beam. The necessary extent of detuning was determined by measuring the transmission of harmonics through the sample. In this procedure, a nitrogen-filled ion chamber is placed immediately behind the helium-filled sample chamber. The fundamental X-ray frequency is completely absorbed by the sample while the third harmonic (at ca. $7.5 \mathrm{keV}$ ) is transmitted with little attenuation through the sample and absorbed in the rear ion chamber. This procedure offers a sensitive test of harmonic rejection.

The data were collected as fluorescence excitation spectra (LYTLE et al., 1984) using a large solid-angle ionization chamber (STERN et al., 1982) as the fluorescence detector. The entire beam path was filled with helium. Since the polypropylene windows of the solution sample cell were permeable to helium, solutions were saturated with helium prior to transfer to the sample holder in order to minimize the formation of helium bubbles in the sample during data collection. The X-ray energy was calibrated by reference to the XANES spectra of elemental sulfur and sodium sulfate run at intervals between the samples. The white-line maximum of the elemental sulfur XANES spectrum was assigned as $2472.7 \mathrm{eV}$, corresponding to an inflection point of $2471.3 \mathrm{eV}$ for elemental sulfur, and a white-line maximum of $2482.6 \mathrm{eV}$ for sulfate (FraNK et al., 1987). ${ }^{\dagger}$ A reproducible dip in the incident beam intensity, corresponding to a sulfate-like material in the beampipe, was used to ensure accurate calibration between runs of the primary calibration standards. The reproducibility of the energy calibration, determined by comparing the spectra for model compounds run at different times, was better than $\pm 0.15 \mathrm{eV}$. Selected models were examined on each of the three beamlines to compare the effects of monochromator resolution on edge features. The average monochromator resolution was estimated to be $\pm 0.5 \mathrm{eV}$.

All spectra were normalized and placed on a quasi-absolute absorption scale by multiplying the data by a scale factor and adding a single low-order polynomial. The data in the pre-edge (2400-2462 $\mathrm{eV})$ and post-edge (2540-2810 eV) regions were constrained to fit tabulated X-ray absorption cross sections (MCMASTER et al., 1969). Normalized fluorescence spectra were then corrected for the linebroadening and attenuating effects of self-absorption using a general expression for fluorescence intensity as a function of sample elemental composition, incident $\mathrm{X}$-ray intensity, and sample thickness.

Since the self-absorption phenomenon (see below) can be described quantitatively (GouLON et al., 1982) as a function of atomic concentrations, it should be possible to develop a procedurc for detcrmining the true absorption spectrum which, when subjected to selfabsorption, gives rise to an observed spectrum. Our correction procedure and the tests of its validity have been described elsewhere in detail (WALDO and PENNER-HAHN, 1991). Briefly, the procedure involves writing a set of equations, $\mu_{\exp }(E)=\mathcal{F}(C, E) \mu_{1 \text { rue }}(E)$, where $\mu_{\text {exp }}$ is the normalized measured spectrum, $\mu_{\text {true }}$ is the true absorption, and 7 is the self-absorption function which depends on energy, $E$, and sample composition, $C$. This set of equations is inverted to solve for $\mu_{\text {true }}(E)$.

The corrected spectra were fitted with linear combinations of model compounds using a non-linear least-squares procedure. Unknown spectra were fit over the range $2465-2485 \mathrm{eV}$, a region which contains the white-line maxima for all of the models (elemental sulfur $=2472.7$ 
$\mathrm{eV}$; sulfate $=2482.6 \mathrm{eV}$ ). The adjustable parameters for each model spectrum were a scaling factor and an optional energy offset. Ideally, the energy offset would not be required. However, several factors can lead to variations in the energy of the sulfur $1 s \rightarrow 3 p$ white-line maximum for chemically similar samples. These include the \pm 0.15 $\mathrm{eV}$ uncertainty of the energy calibration, solvent shift effects $( \pm 0.2$ $\mathrm{eV}$ ), and inductive effects (ca. $\pm 0.3 \mathrm{eV}$ ) (see below). If a small energy offset is not included in the fitting, large uncertainties are introduced in the quantitation, especially for quantitation of low concentration species. The magnitude of the energy offset for the major components was within the uncertainty of the calibration.

\section{RESULTS AND DISCUSSION}

\section{Quantitative Analysis of XANES Spectra}

A high degree of correlation has been observed between sulfur oxidation state and the energy of the white-line (FRANK et al., 1987). We have enlarged this series to include sulfur compounds found in petroleums. Figure 1 illustrates the variation in white-line energy for each of the classes of sulfur model compounds considered in this study. Since energies can be determined with an uncertainty of ca. $\pm 0.15 \mathrm{eV}$ but differ by nearly $10 \mathrm{eV}$ for different sulfur compounds, it is clear that sulfur XANES spectroscopy has great potential for determining sulfur speciation. The sulfoxy classes are well separated-the formal oxidation state of the sulfur increases by two with the addition of each oxo group. Although similar in formal oxidation states, thiophenes are readily distinguished from sulfides and disulfides on the basis of the position of white-line maxima alone. However, variations in electron density (as indicated by the white-line energy) for sulfur, sulfides, and disulfides are not as great as for the aromatic and sulfoxy compounds. For example, elemental sulfur and benzyl disulfide cannot be distinguished on the basis of edge energy alone. In addition, there is considerable overlap of the sulfur white-line maxima for the sulfide and disulfide classes.

When fluorescence excitation spectra are used to measure absorption for thick, concentrated samples (as was the case for many of the samples), the spectra are severely distorted

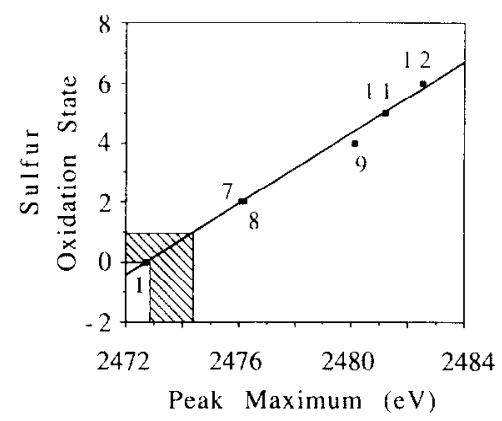

FIG. 1. Plot of sulfur K-edge X-ray absorption white-line maxima (eV) vs. oxidation state for selected models: (1) elemental sulfur; (7) benzyl sulfoxide; (8) phenyl sulfoxide; (9) dibenzothiophene sulfone; (11) cysteic acid; (12) sulfate. Data were fitted with a Icast-squares line $(r=0.99)$. Oxidation state assignments are given in Table 1 . The range of white-line maxima for the alkyl disulfide, alkyl sulfide, and thiophenc models and their apparent oxidation states (from the bestfit line) are indicated by the cross-hatched region.

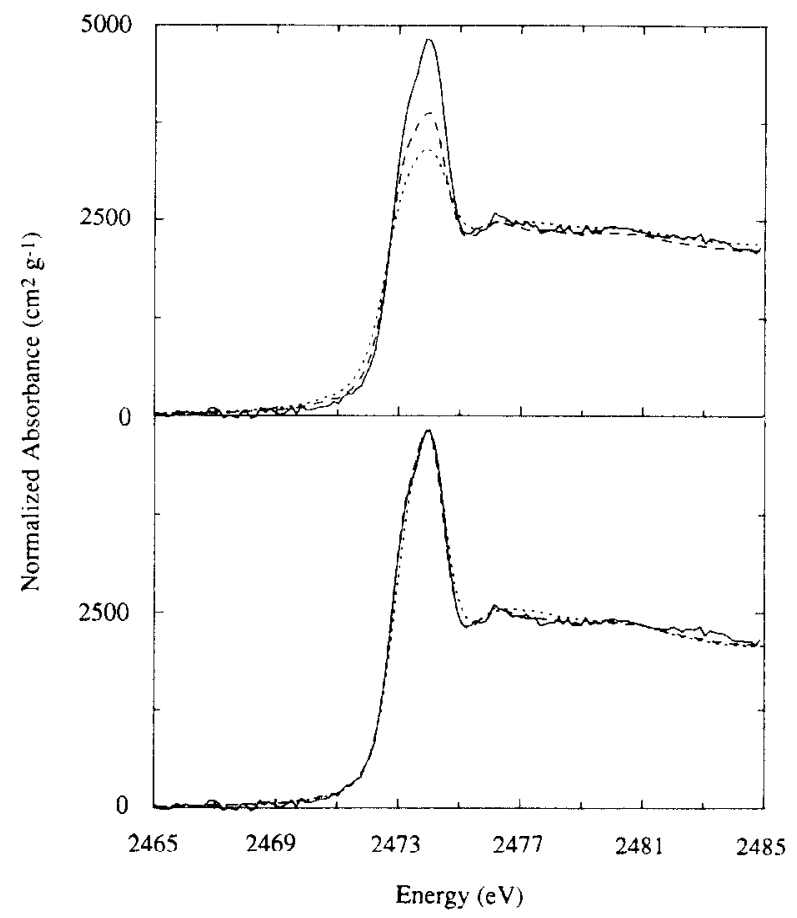

FIG. 2. Effect of self-absorption on sulfur XANES spectra. (top) Sulfur XANES spectra measured for a petroleum containing $8.0 \mathrm{wt} \%$ sulfur (short dash) and the same sample diluted in o-xylene to 2.8 wt $\%$ sulfur (long dash) and $0.28 \mathrm{wt} \%$ sulfur (solid). The severe attenuation due to self-absorption is apparent. (bottom) The same spectra as in (top) after correction for self-absorption as described in text.

due to self-absorption. Figure 2 (top) shows that both the widths and the relative heights of the XANES features are dependent on concentration. The normal response to this problem is either to use transmission mode for data collection or to dilute the sample to the point that self-absorption is negligible. The former is impractical for low energy studies (e.g., sulfur K-edge) since samples typically cannot be made sufficiently thin (ca. $1-10 \mu \mathrm{m}$ for concentrated samples). The latter gives an inevitable decrease in signal/noise ratio. Moreover, dilution can be difficult or impossible for insoluble samples. Although good results have been obtained by diluting solid samples in a non-absorbing matrix (e.g., boron nitride) (GEORGE and GORBATY, 1989; FRANK et al., 1987), the particle size of the analyte must be small compared to the absorption cross-section for sulfur in the sample in order to obtain undistorted spectra.

Our goal was to use sulfur XANES spectroscopy to determine sulfur speciation in petroleum and petroleum source rocks. For these samples, significant self-absorption occurs for thick samples if the sample has $\geq 0.3 \mathrm{wt} \%$ sulfur. Although some samples could be prepared as thin layers $(t \sim 30 \mu \mathrm{m})$, self-absorption remains a problem if the sulfur concentration is greater than ca. $5 \mathrm{wt} \%$. Although self-absorption is at most a minor concern in qualitative studies, it was essential that we correct for it in order to obtain quantitative results. As a test of our self-absorption correction procedure, we compared spectra for a concentrated sample (a heavy oil containing 8.0 $w t \%$ sulfur) and for solutions of the oil diluted to 2.8 and 
Table 1. Sulfur K-edge peak energles. oxidation states and areas for model compounds.

\begin{tabular}{r|l|l|c|c}
\hline$\#$ & Compound & Peak (eV) & $\begin{array}{c}\text { Peak } \\
\text { Area }\end{array}$ & $\begin{array}{c}\text { Oxddation } \\
\text { State }\end{array}$ \\
\hline & Elemental Sulfur & 2472.7 & 110 & 0.0 \\
2 & Benzyl Disulfide & 2472.9 & 102 & $0.0^{2}$ \\
3 & Benzyl Sulfide & 2473.4 & 103 & $0.3^{2}$ \\
4 & l-cysteine & 2473.5 & 97 & $0.4^{2}$ \\
5 & dl-methlonine & 2473.7 & 99 & $0.5^{2}$ \\
6 & 2-hexadecylthiophene & 2474.1 & 102 & $0.7^{2}$ \\
7 & Benzyl Sulfoxdde & 2476.1 & 150 & 2.0 \\
8 & Phenyl Sulfoxdde & 2476.2 & 140 & 2.0 \\
9 & Dibenzothiophene Sulfone & 2480.1 & 186 & 4.0 \\
10 & Phenyl Sulfone & $2480.9^{3}$ & $201^{3}$ & \\
11 & Cyslelc Acid & 2481.2 & 226 & 5.0 \\
12 & Sodium Sulfate & 2482.6 & 239 & 6.0 \\
\hline
\end{tabular}

${ }^{1}$ XANES spectra were normalized to the atomic $X$-ray absorption cross section of sulfur. Peak areas have units of $\mathrm{eV} \cdot \mathrm{cm}^{2} / \mathrm{g}$.

2 Oxidation state calculated from best fit line (Fig. 1). The calculated axidation states for cysteine and methionine are consistent with those obtained previously (FRANK et al., 1987).

3. The white-line for phenyl sulfone is strongly split. The area was obtained by fitting both of the edge peaks with Gaussians. The energy was assigned as the weighted sum for the Gaussians.

$0.28 w t \%$ sulfur in o-xylene. Conventional normalization yielded spectra whose edge features differed by nearly $30 \%$ in amplitude (Fig. 2, top). When corrected for self-absorption these spectra agreed to within $4 \%$ (Fig. 2, bottom).

\section{Resolution of Multicomponent Systems}

As noted previously, elemental sulfur, sulfides, and disulfides all have similar absorption edge energies. Since all of these are likely to be present in gcological samples, it is crucial to determine the quantitation uncertainties for mixtures of these species. Specifically, is it possible to quantitatively resolve a mixture containing both sulfur and a disulfide?

As one test of this question, the XANES spectrum of an o-xylene solution containing elemental sulfur (7.29 mM), benzyl disulfide $(56.0 \mathrm{mM})$, and phenyl sulfone $(51.8 \mathrm{mM})$, was fitted with linear combinations of the appropriate models. Two fitting protocols were employed. In the first, only the scaling parameters were optimized in a linear least-squares analysis, while in the second, both scaling and energy-offset parameters were varied in a non-linear least-squares fit. For both protocols, the absolute quantitation agreed with the actual concentrations to within ca. $2 \%$.

For the scale factor-only protocol, correlation effects were addressed using singular value analysis. The XANES spectra of sulfur and benzyl disulfide show a low degree of correlation. Although the sulfur and disulfide $1 \mathrm{~s} \rightarrow 3$ p peaks lie at nearly

${ }^{\ddagger}$ A $2476 \mathrm{eV}$ feature has also been reported on the high-energy side of the sulfur XANES spectrum of dibenzothiophene (HUFFMAN et al., 1990; GEORGE and GORBATY, 1989). This feature could interfere with sulfoxide quantitation. We have measured the sulfur XANES spectrum for dibenzothiophene prepared to minimize self-absorption by grinding with boron nitride. This spectrum is very similar to that for 2-hexadecylthiophene. Both spectra lack the previously reported sharply defined structure at ca, $2476 \mathrm{eV}$, suggesting that our "sulfoxide" component truly represents sulfoxide rather than simply a high-energy feature from the thiophene components. the same energy (see Fig. 1 and Table 1), these species can still be resolved due to the structural richness of the higherenergy sulfur XANES. In the non-linear protocol, the offsets for the major components (disulfide and sulfoxide) were negligible, as expected. The shift of the sulfur was $-0.15 \mathrm{eV}$, also within the estimated experimental uncertainty.

These tests demonstrate that our normalization and selfabsorption correction protocols can be used to obtain a quantitative resolution of simple mixtures. Unfortunately, oil is not a simple mixture of a few components but instead contains numerous different organo-sulfur compounds. Although chemically distinct forms of sulfur can be both distinguished and quantitated, it does not appear possible to resolve chemically similar components (e.g., sulfides and disulfides) in a complex, unknown mixture such as oil.

\section{Sulfur XANES Spectra of Petroleums}

The petroleum samples for which sulfur XANES spectra were measured are listed in Table 2 . The majority of the petroleums have XANES spectra similar to that for the Wyoming crude shown in Fig. 3. The principal components of these samples are thiophenic ( $2474 \mathrm{eV}$ peak), with varying amounts of a sulfide/disulfide-like species ( $2473 \mathrm{eV}$ shoulder). Some of the low-sulfur lacustrine oils also contain a sulfoxidelike species $\left(2476 \mathrm{eV}\right.$ peak). ${ }^{\ddagger}$ Other exceptions include the high-temperature hydrous pyrolysis samples, which contain a species close to sulfur/disulfide in oxidation state, and the source rock extracts, which contain substantial sulfonic acid and $\mathrm{SO}_{4}^{2-}$.

Although most of the oil samples exhibited some structure in the $2477-2480 \mathrm{eV}$ range, and a broad peak at $2480.8 \mathrm{eV}$ (nominally sulfone-like), no attempt was made to include appropriate models for this structure in the basis set. The higher energy peaks correspond to less than $5 \%$ of the total sulfur. Moreover, the inevitable presence of higher energy peaks arising from lower oxidation-state sulfur functional 
TABLE 2

XANES ANALYSES OE PETROLEUM SAMPLES, PYROLYSATES AND PETROLEUM FRACTIONS

\begin{tabular}{|c|c|c|c|c|c|c|}
\hline $\begin{array}{l}\text { Sample } \\
\text { No. }\end{array}$ & Location or Identity & Source/Age & $\begin{array}{c}\text { wt } 8 \\
\text { Sulfur }\end{array}$ & $\begin{array}{c}8 \\
\text { Sulfide } \\
\end{array}$ & $\begin{array}{c}\text { Th } \\
\text { Thiophene } \\
\end{array}$ & Sulfoxide \\
\hline & California, U.S.A. & & & & & \\
\hline 1 & Santa Maria/Santa Barbara & Monterey Fm (Marine)/Miocene & 8.00 & 38 & 60 & 2 \\
\hline 2 & Santa Maria/Santa Barbara & Monterey Fm (Marine) /Miocene ${ }^{6}$ & 4.65 & 33 & 57 & 10 \\
\hline 3 & Santa Maria/Santa Barbara & Monterey Fm (Marine)/Miocene 6 & 3.70 & 31 & 63 & 6 \\
\hline 4 & Santa Maria/Santa Barbara & Monterey Fm (Marine) /Miocene & 2.22 & 40 & 56 & 4 \\
\hline \multirow[t]{2}{*}{5} & Santa Maria/Santa Barbara & Monterey Fm (Marine)/Miocene ${ }^{6}$ & 0.86 & 16 & 79 & 5 \\
\hline & Adriatic & & & & & \\
\hline 6 & Katia & Carbonate (Marine)' & 6.2 & i. 1 & 82 & 8 \\
\hline 7 & Santa Maria & Carbonate (Marine)? & 5.5 & 6 & 88 & 6 \\
\hline 8 & Rovesti & Carbonate (Marine)? & 2.7 & $?$ & 85 & 8 \\
\hline $9^{3}$ & Fillentino & Carbonate (Marine)' & 11.5 & 9 & 83 & 9 \\
\hline \multirow[t]{2}{*}{10} & Vinese & Carbonate (Marine)? & 7.0 & 18 & 76 & 6 \\
\hline & Wyoming, U.S.A. & & & & & \\
\hline 11 & Hamilton Dome Fd & Phosphoria Em (Marine)/Permian & 2.60 & 15 & 78 & 7 \\
\hline \multirow[t]{2}{*}{12} & Middle East & Carbonate (Marine)" & 2.35 & 12 & 86 & 2 \\
\hline & Utah, U.S.A. & & & & & \\
\hline 13 & Rozel point & Shale (Lacustrine)/Miocene ${ }^{10}$ & 13.96 & 36 & 60 & 4 \\
\hline 14 & Rozel Point & Shale (Lacustrine)/Miocene ${ }^{10}$ & 13.69 & 34 & 60 & 5 \\
\hline 15 & Rozel Point & Shale (Lacustrine)/Miocene ${ }^{10}$ & 13.47 & 38 & 59 & 3 \\
\hline 16 & Uinta Basin & Green River Fm (Lacustrine)/Eocene ${ }^{11}$ & 0.21 & 23 & 51 & 26 \\
\hline $16^{4}$ & Uinta Basin & Green River Fm (Lacustrine)/Eocene ${ }^{11}$ & 0.21 & 8 & 55 & 37 \\
\hline 17 & Uinta Basin & Green River Fm (Lacustrine)/Eocene ${ }^{11}$ & 0.44 & 19 & 54 & 28 \\
\hline 18 & Uinta Basin & Green River Fm (Lacustrine)/Eocene ${ }^{11}$ & 0.19 & 19 & 61 & 20 \\
\hline 19 & Uinta Basin & Green River Fm (Lacustrine)/Eocene & 0.15 & 18 & 61 & 21 \\
\hline $19^{4}$ & Uinta Basin & Green River Fm (Lacustrine)/Eocene 11 & 0.15 & 4 & 69 & 27 \\
\hline 20 & Uinta Basin & Green River Fm (Lacustrine)/Eocene ${ }^{11}$ & 0.07 & 12 & 64 & 25 \\
\hline 21 & Uinta Basin & Green River Fm (Lacustrine)/Eocene ${ }^{11}$ & 0.31 & 8 & 72 & 21 \\
\hline 22 & Uinta Basin & Green River Fm (Lacustrine)/Eocene ${ }^{11}$ & 0.06 & i. 7 & 70 & 13 \\
\hline \multirow[t]{2}{*}{$23^{5}$} & Uinta Basin & Green River Fm (Lacustrine)/Eocene ${ }^{11}$ & 0.65 & 30 & 65 & 5 \\
\hline & China & & & & & \\
\hline \multirow[t]{2}{*}{24} & Shengli $\mathrm{Em}$ & Shahejie shale (Lacustrine)/o1igocene ${ }^{12}$ & 0.98 & 22 & 73 & 5 \\
\hline & United Kingdom & & & & & \\
\hline \multirow[t]{2}{*}{25} & North Sea & Kimmeridge shale (Marine)/Jurassic ${ }^{1,3}$ & 0.54 & 9 & 82 & 9 \\
\hline & Pyrolysates & & & & & \\
\hline $26^{: 4}$ & siliceous Member & Monterey Fn (Marine)/Miocenes & 8.91 & 12 & 77 & ì \\
\hline $27^{15}$ & Siliceous Member & Monterey $\mathrm{Fm}$ (Marine)/Miocene ${ }^{6}$ & 5.25 & 6 & 89 & $\begin{array}{r}1 \\
5\end{array}$ \\
\hline $28^{14}$ & Phosphatic Member & Monterey Ftn (Marine) /Miocene ${ }^{6}$ & 8.01 & 10 & 82 & 8 \\
\hline \multirow[t]{2}{*}{$29^{15}$} & Phosphatic Member & Monterey Fr (Marine)/Miocene ${ }^{6}$ & 5.54 & 8 & 86 & 6 \\
\hline & Petroleum Fractions & & & & & \\
\hline & California:th & Monterey Fm (Marine)/Miocene ${ }^{6}$ & & & & \\
\hline 30 & Maltenes & & 8.79 & 39 & 60 & 1 \\
\hline 31 & Asphaltenes & & 9.48 & 31 & 67 & 2 \\
\hline 32 & Aromatic Fr. & & 8.04 & 25 & 75 & $<1$ \\
\hline 33 & NSO Fr. & & 9.53 & 40 & 55 & 5 \\
\hline & Utah:? & Shale (Lacustrine)/Miocene ${ }^{10}$ & & & & \\
\hline 34 & Maltenes & & 13.31 & 41 & 58 & $\lambda$ \\
\hline 35 & Asphaltenes & & 14.50 & 34 & 63 & 2 \\
\hline \multirow{3}{*}{$\begin{array}{l}36 \\
37\end{array}$} & Aromatic Fr. & & 10.62 & 16 & 84 & $<1$ \\
\hline & NSO Er. & & 14.23 & 41 & 56 & 4 \\
\hline & Utan ${ }^{18}$ & Green River Fmi (Lacustrine)/Eocene": & & & & \\
\hline 38 & Asphaltenes & & 0.19 & 5 & 60 & 35 \\
\hline 39 & Maltenes & & 0.19 & 12 & 61 & 27 \\
\hline
\end{tabular}

$\frac{1}{2}$ Wt $z$ sulfur in whole crude oil.

Percent of total sulfur.

Reservoir rock extract.

5 Sample stored for nver one year without exclusion ni oxygen.

Gilsonite solid bitumen, an immature petroleum (Hunt, 1979).

7 Orr, 1986.

Moldowar et al., 1989.

9 Orr, 1974

9 Ayres et al. 1982

Bortz, 1984.

12 Hunt el a1., 1954.

12 Shi et a1..' 1982 .

13 peters et al.o 1989 .

14 peters et al $300^{\circ} \mathrm{C}$ for 72 hours.

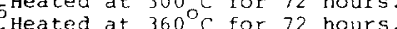

${ }_{7}$ Petroleum Sample No. 1 .

17 Petroleum Sample No. 15.

8 petroleum Sample No. 15. 


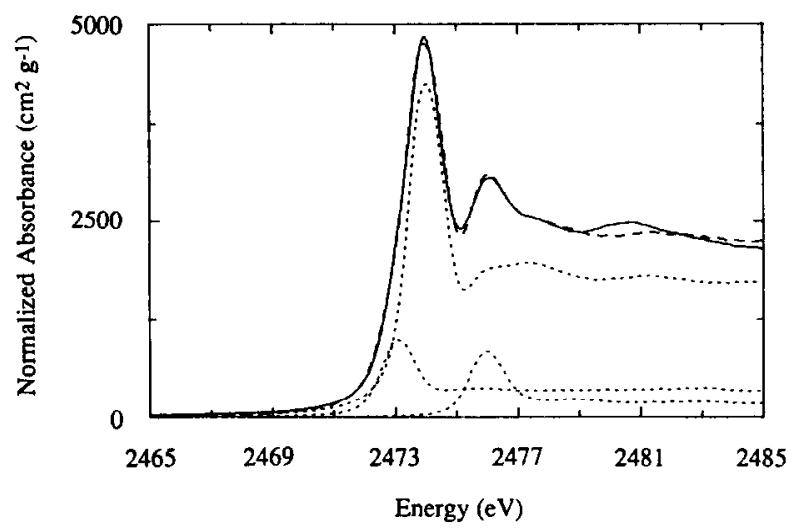

FIG. 3. Sulfur XANES spectrum of a representative petroleum (Wyoming crude, sample 11, Table 2). Solid line: experimental spectrum after correction for self-absorption. Principal component is thiophene-rich ( $2474 \mathrm{eV}$ peak) with smaller contributions from sulfidic ( $2473 \mathrm{eV}$ shoulder) and sulfoxide (2476 eV peak) components. Dotted lines: optimal basis set for least-squares fitting, consisting of benzyl sulfide, 2-hexadecyl thiophene and benzyl sulfoxide. Dashed line: sum of the models. The broad feature at $2480.8 \mathrm{eV}$ (sulfonelike) corresponds to less than ca. 5\% of the total sulfur. Models for this feature were not included in the basis set.

groups precludes quantitative analysis of the $2477-2480 \mathrm{eV}$ peaks. A feature at ca. $2484 \mathrm{eV}$ appears to be systematically enriched in the maltene aromatic hydrocarbon fraction of the various high-sulfur marine and Rozel Point samples. It is not clear what structural features may give rise to this peak.

The optimal set of model compound spectra for modeling the petroleum XANES spectra was benzyl sulfide, 2-hexadecylthiophene, and benzyl sulfoxide. ${ }^{\S}$ The energy shifts for the thiophene and sulfoxide models (features at 2474 and $2476 \mathrm{eV}$, respectively) were within the uncertainty of the calibration. However, in the absence of energy offset parameters, no single model, nor any pair of models, could be used to fit the $2473 \mathrm{eV}$ disulfide/sulfide-like shoulder. The offset was typically less than $0.2 \mathrm{eV}$ and was in no case greater than $0.4 \mathrm{eV}$. This shoulder can be isolated by subtracting the thiophenic component from the overall spectrum. The peak in this difference spectrum appears to be too narrow to arise from a mixture of species with different oxidation states. This peak lies between the highest energy disulfide $(2472.8 \mathrm{eV})$ and lowest energy sulfide $(2473.4 \mathrm{eV})$. Although it is most similar to the sulfide models in shape, it is slightly closer to the disulfide models in energy. We cannot assign this sulfide/ disulfide feature to a specific sulfur-containing functionality. However, we can exclude free elemental sulfur as the origin of the $2473 \mathrm{eV}$ peak, since the mean square deviation in the fit doubles when sulfur is used in place of a sulfide/disulfide model. Although the magnitude of the energy offset depends on the model used, all of the models are shifted to the same final position. This confirms that the refined position of the peak is not an artifact, and is not influenced by correlation

\footnotetext{
\& Other thiphenes, e.g., dibenzothiophene, have XANES spectra that agree with that for 2-hexadecylthiophene to within the uncertainty in the calibration. The latter was used as the thiophene reference since its spectrum was measured under conditions which minimized self-absorption.
}

with the thiophenic model. Those models which required smallest offsets are probably most similar chemically to the oil components which give rise to the $2473 \mathrm{eV}$ feature. These components will be referred to as sulfides in the following discussion.

Although unambiguous chemical identification of the 2473 $\mathrm{eV}$ peak is not possible, quantitation is still feasible since the different sulfide and disulfide models gave the same fraction for this peak (to within $10 \%$ ). This simply reflects the fact that the area of the sulfur white-line is, in a simple one-electron model, proportional to the number of $3 p$ vacancies and thus should increase as the oxidation state increases. A plot of white-line area vs. peak position shows an approximately linear increase in the area with increasing energy (Fig. 4). In principle, this correlation could be used for approximate quantitation in the absence of a model of the appropriate oxidation state. Of more practical importance, however, is the justification this offers for basing quantitation on a chemical model which is not identical to the unknown. Models and unknowns with similar peak energies (i.e., similar oxidation states) are expected to have similar peak areas. This was confirmed by simulations in which a synthetic spectrum produced by summing various fractions of two or more models was fit using different, but chemically similar, models. These fits were correct to within $15 \%$ relative error.

\section{Sulfide-Rich vs. Thiophenic High-Sulfur Petroleums}

The high-sulfur (greater than $1.0 \mathrm{wt} \%$ sulfur) petroleums have two distinct sulfide/thiophene/sulfoxide compositional profiles (Fig. 5). Oils from the Santa Maria/Santa Barbara area of California, with total sulfur from 2.2 to $8.0 \mathrm{wt} \%$ (Table 2), all have organosulfur compositions near the sulfide corner of the relevant section of the XANES-derived ternary diagram (Fig. 5). The Rozel Point, Utah, oils, with sulfur between 13 and $14 \mathrm{wt} \%$, have sulfide/thiophene/sulfoxide compositions similar to the California oils. The sulfide content of both the Santa Maria/Santa Barbara and the Rozel Point oils is above $30 \%$ of total sulfur and the thiophene content less than $65 \%$. Although the thiophene components̀ still dominate the organosulfur distribution, these oils contain significantly higher

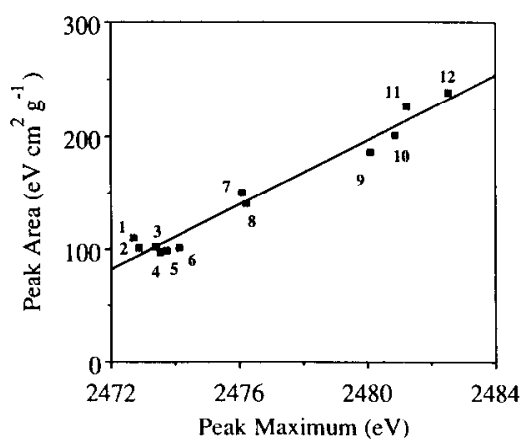

FIG. 4. Dependence of white-line peak area on peak energy. Areas determined by numerical integration over a $5 \mathrm{eV}$ interval centered on the peak maximum (Table 1). Solid line is the least-squares fit of area as a linear function of peak energy. The area of the sulfur whiteline feature increases with increasing sulfur oxidation state, proportional to the number of $3 p$ vacancies. 


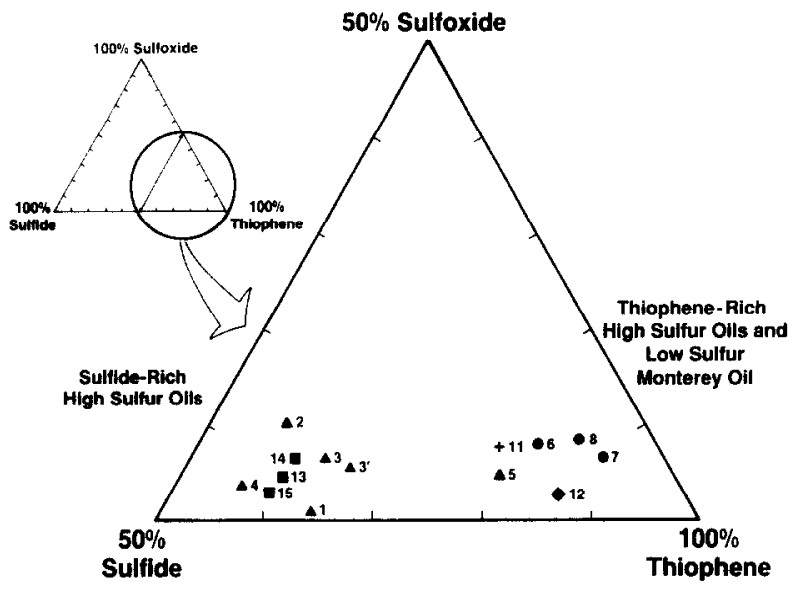

FIG. 5. Organosulfur compositional differences between high-sulfur petroleums (sulfur content ranging from 2.35 to $13.96 \mathrm{wt} \%$ ) shown by sulfur XANES analyses: (A) California (Santa Maria/Santa Barbara

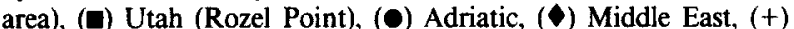
Wyoming. Sample numbers (see Table 2) are listed by the data points. The Monterey oils $(\Delta)$ all have high-sulfur (greater than $1.0 \mathrm{wt} \%$ sulfur) with the exception of sample 5 . Axes range from 0 to $50 \%$ (of total sulfur) for sulfides and sulfoxides, and from 50 to $100 \%$ (of total sulfur) for thiophenes.

concentrations of sulfides. We will refer to these oils as sulfiderich, high-sulfur oils in subsequent discussions. In contrast, the Adriatic, Wyoming (Hamilton Dome), and Middle Eastern high-sulfur oils (with sulfur from 2.35 to $6.2 \mathrm{wt} \%$ ) all have organosulfur compositions near the thiophene corner in Fig. 5. Because thiophene is above $75 \%$ and sulfide below $15 \%$ for each of these oils, we refer to them as thiophenerich high-sulfur oils.

The organosulfur compositional differences between the thiophene-rich and sulfide-rich high-sulfur oils appear to arise from differences in the early diagenesis of the sediments which formed the source rocks for the oils. The quantity of sulfur in the high-sulfur oils is too high to be derived solely from sulfur-containing biochemicals in the primary source organic matter (GRANSCH and POSTHUMA, 1974; ORR, 1986). Instead, sulfur in the high-sulfur oils must have been introduced either during source-rock diagenesis (SINNINGHE DAMSTE et al., 1988b) or by some secondary process. Our data are consistent with an abiogenic source of the organosulfur compounds in these oils. Thus, the Santa Maria/Santa Barbara oils, which are sourced from marine-derived shales of the Miocene Monterey formation (CURIALE et al., 1985; CURIALE and ODERMATT, 1989; ORR, 1986), and the Rozel Point oils, which are sourced from lacustrine-derived shales (BORTZ, 1984), have similar sulfide/thiophene/sulfoxide compositional profiles despite their different organic matter sources (marine vs. lacustrine). Rozel Point oil contains thiolanes (SCHMID et al., 1987; SINNINGHE DAMSTÉ et al., 1987) which would have been destroyed during microbial biodegradation (FEDORAK et al., 1988); therefore, it is unlikely that this is a severely biodegraded oil. Similarities in early diagenetic conditions appear to have resulted in high concentrations of similar highly reduced sulfide-rich organosulfur functional groups in proto-kerogens of these two source rocks. Important conditions may include the availability of olefinic groups in the organic matter into which sulfur is incorporated, the levels of dissolved sulfate, activity of sulfate-reducing bacteria (e.g., Desulfovibrio) vs. hydrogen sulfide-oxidizing bacteria (e.g., Thiobacillus), redox conditions, and/or the availability of pyrite-forming $\mathrm{Fe}^{2+}$ during diagenesis.

The sulfide-rich, high-sulfur oils were all derived from shale source rocks, although the Monterey Phosphatic member contains ca. $10 \%$ dolomite. However, both the Adriatic (MOLDOWAN et al., 1989) and the Middle Eastern (AYRES et al., 1982) thiophene-rich high-sulfur oils were derived from carbonate source rocks. Oils derived from carbonate source sequences are known to have higher average sulfur contents than those from clastic sequences (TISSOT and WELTE, 1984). Differences in the content and distribution of benzothiophene in the volatile fractions of oils derived from clastic vs. carbonate source sequences have been reported previously (HUGHES, 1984). Although further studies are needed, these initial XANES measurements suggest that high-sulfur thiophene-rich oils may be associated with carbonate sources whereas high-sulfur sulfide-rich oils may be associated with clastic sources. The Wyoming (Hamilton Dome) oil, believed to be sourced by the Permian Phosphoria formation, does not appear to fit this clastic/carbonate trend, although detrital clastics are very limited in the phosphoria source facies. Also, the Hamilton Dome oils show signs of slight biodegradation which could affect these results. Furthermore, other factors (e.g., thermal maturity) are also known to affect the total thiophene/sulfide ratio of crude oils (Ho et al., 1974; KOHNEN et al., 1990b). Future experiments will seek to determine the relative importance of source sequence and thermal maturity.

\section{Petroleum Maturation}

Petroleum is generated from source-rock formations by thermally induced cracking reactions over geologic time (TISSOT and WELTE, 1984). This catagenesis process includes progressive dehydrogenation (aromatization) reactions. Thus, the progressive dehydrogenation of petroleum biological markers (fossil compounds) can be used to assess crude oil thermal maturity (SEIFERT and MOLDOWAN, 1986). One biological marker conversion which has been used to gauge crude oil maturity is the aromatization of ring-C monoaromatic steroid hydrocarbons to triaromatic steroid hydrocarbons shown in Scheme 1 (MACKENZIE, 1984; MACKENZIE et al., 1981; SHI et al., 1982). This biological marker reaction has been used successfully to model petroleum generation

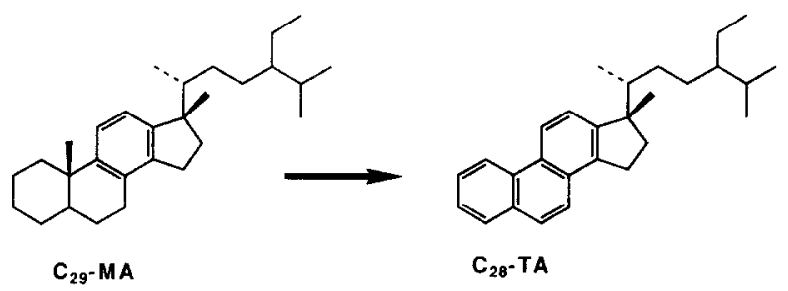

SCHEME 1. 
processes in petroleum exploration basin modeling (MCKenZiE et al., 1983; BEAUMONT et al., 1985).

Petroleum source rocks contain elemental sulfur, which is known to be a good dehydrogenating agent in model geochemical maturational studies (DOUGLAS and MAIR, 1965). Some of the products formed during sulfur-induced dehydrogenation reactions are thiophene-rich molecules, suggesting that thiophene content and thermal maturity may be related. Therefore, we compared the thermal maturity of Adriatic crude oils and reservoir rock extracts (Table 2), measured as the monoaromatic to triaromatic steroid hydrocarbon ratios (MOLDOWAN et al., 1989), to percent thiophene content. This comparison, shown in Fig. 6, suggests a link between thermal maturity and the proportion of thiophene sulfur in these oils. This relationship may result from the conversion of more labile sulfide moieties to thiophene-containing compounds. Alternatively, the increased proportions of thiophene in more thermally mature crude oils may reflect the more refractory nature of thiophenes compared to many organosulfides (Ho et al., 1974). Artificial maturation studies (below) favor the latter mechanism.

The sulfur content of crude oils has been linked to thermal maturity (Ho et al., 1974). Within a set of related crude oils, those with lower sulfur content generally show greater thermal maturity, as long as secondary processes (e.g., biodegradation) have not affected the oils. For this reason, it was of interest to compare the sulfide/thiophene/sulfoxide profiles of highsulfur (greater than $1.0 \mathrm{wt} \%$ sulfur) and low-sulfur (less than $1.0 \mathrm{wt} \%$ sulfur) oils derived from the same source rock. In Fig. 5, sulfur XANES profiles are shown for four high-sulfur and one low-sulfur Monterey formation-sourced oils. Whereas no compositional trend is apparent between organosulfur composition and sulfur percentages (2.2 to 8.0 wt\% sulfur, Table 2) of the high-sulfur oils, the low-sulfur oil (0.86 wt\% sulfur, Table 2 ) contains a distinctly higher proportion of thiophenes than the high-sulfur crudes. Additional analyses are needed to determine if a general trend exists, however, these preliminary results provide further support for the postulated correlation between thermal maturity and thiophene content.

\section{Artificial Maturation Studies (Hydrous Pyrolysis)}

Generation and maturational transformations of petroleum can be studied using hydrous pyrolysis experiments on petroleum source rocks (LEWAN, 1985). This provides an experimental method for directly assessing the effect of thermal maturity on crude oil organosulfur compositions. During both hydrous pyrolysis and natural burial maturation, the insoluble, particulate organic matter (kerogen) in petroleum source rocks is cracked to produce bitumen and expelled oil. In our hydrous pyrolysis experiments, bitumen is defined as the soluble petroleum remaining in the core chips, while expelled oil has escaped from the chips. The Monterey source rock used in the hydrous pyrolysis experiments contains kerogen having a high (8-10 wt\%) organic sulfur content (PETERS et al., 1990). The expelled oil has been previously characterized with respect to biomarker thermal maturity (PETERS et al., 1990).

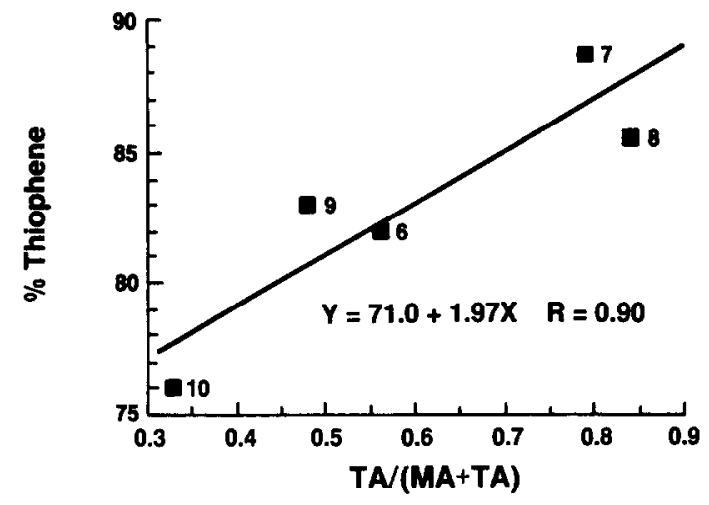

FIG. 6. Relationship between the ratio of triaromatic steroids (TA) and monoaromatic steroids (MA) to total thiophene (percent of total sulfur) determined by XANES analyses of Adriatic oils and extracts. The ratio TA/(MA + TA) increases with petroleum thermal maturity. Sample numbers (see Table 2) are listed by the data points.

We have used sulfur XANES spectroscopy to investigate sulfur speciation in high-sulfur Monterey source-rock hydrous pyrolysis products. This has allowed us to explore the effect of pyrolysis temperature $\left(300\right.$ or $360^{\circ} \mathrm{C}$ ) and source-rock composition (Siliceous or Phosphatic) on organosulfur composition. For the samples studied, increasing thermal maturity results in apparent loss of sulfide and sulfoxide, and relative enrichment in thiophene moieties (Table 2, Fig. 7). LECO sulfur analysis shows that the expelled oil generated from the Monterey Siliceous member at 300 and $360^{\circ} \mathrm{C}$ contains 8.91 and $5.26 \mathrm{wt} \%$ sulfur, respectively, while that generated from the Phosphatic member at the same temperatures contains 8.01 and $5.54 \mathrm{wt} \%$ sulfur, respectively. The observation that the decrease in total sulfur mirrors the relative decrease in sulfide and sulfoxide suggests that thermal maturation causes selective loss of thermally labile sulfide and sulfoxide while the more refractory thiophene-rich sulfur species remain intact. The alternate hypothesis, that dehydrogenation reactions convert labile cyclic sulfide moieties into thiophene-rich groups, is less consistent with these data, although it is possible that both mechanisms contribute to the observed change in organosulfur distribution.

Finally, it should be noted that the overall sulfur speciation in the hydrous pyrolysates (Fig. 7) does not show a close match to sulfur speciation in the Monterey oils (Fig. 5). The sulfide-like component in the pyrolysates occurs at a slightly $(0.4 \mathrm{eV})$ lower energy than the sulfide components observed in any of the other oils. This may indicate an increased contribution of disulfides or polysulfides to this peak. In addition, the pyrolysates appear to contain too high a proportion of thiophenes, in comparison to that expected for Monterey oils. This may be due to facies differences between the source rocks of the Monterey oils studied to date and the organicrich rock from the Bradley Lands core. Alternatively, these differences may indicate that the organosulfur reactions which occur quickly at the very high temperatures $\left(300\right.$ and $\left.360^{\circ} \mathrm{C}\right)$ used in the hydrous pyrolysis experiments do not correlate well with the organosulfur reactions which occur very slowly at the much lower temperatures found during natural sourcerock maturation. 


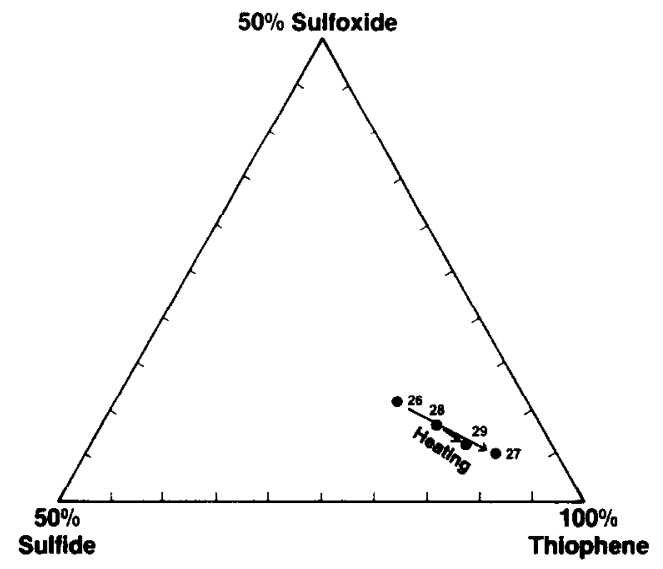

FIG. 7. Thermal maturity-related organosulfur transformations indicated by sulfur XANES analyses of oils generated by hydrous pyrolysis of Monterey Formation, California, source rock (Bradley Lands No. 5-74, Santa Maria Valley). (a) Siliceous member (5419-5425 ft.) sample 26 heated $72 \mathrm{~h}$ at $300^{\circ} \mathrm{C}$; sample 27 heated $72 \mathrm{~h}$ at $360^{\circ} \mathrm{C}$. (b) Phosphatic member (5649-5655 ft.), sample 28 heated $72 \mathrm{~h}$ at $300^{\circ} \mathrm{C}$; sample 29 heated $72 \mathrm{~h}$ at $360^{\circ} \mathrm{C}$. Sample numbers (see Table 2) are listed adjacent to data points.

\section{Organosulfur Compounds of Crude Oil Fractions}

Petroleum asphaltenes are a solubility class, with the asphaltene fraction of a crude oil defined as that material which precipitates from the oil when an excess (usually 40 -fold by volume) of a light $n$-paraffin hydrocarbon such as $n$-pentane, $n$-hexane, or $n$-heptane is added to the oil (SPEIGHT, 1980). The portion of oil that remains in solution is termed the maltene fraction or deasphalted oil. Asphaltenes and maltenes are thus not well-defined compositional classes, although asphaltenes tend to contain more high molecular weight and/ or highly polar compounds (BODUSZYNSKI, 1987). Geochemical studies show many compositional similarities between the asphaltene fraction and the source-rock kerogen from which the oil was generated, suggesting that asphaltenes may represent intermediates in the conversion of kerogen to crude oil hydrocarbon fractions.

A recent report (GEORGE and GORBATY, 1989) demonstrated the application of sulfur XANES spectroscopy to the direct analysis of the organosulfur composition of petroleum asphaltene fractions. These authors demonstrated that there can be significant differences in the thiophene content of asphaltene fractions. We have extended this approach to investigate a series of asphaltenes of well-defined geochemical origin and have attempted to quantitate the sulfur composition of these samples.

We have studied the asphaltene and maltene fractions, and the liquid chromatographic (LC) fractions derived from the maltenes, for three crude oils. The compositional profiles for two of the crude oils (Rozel Point, Sample No. 15, and Santa Maria/Santa Barbara, Sample No. 1) are given in Table 2. The fractions from the third crude oil (Uinta Basin, Sample No. 18) showed evidence of autooxidation (see below).

Both samples 1 and 15 are sulfide-rich, high-sulfur oils. They are, however, derived from significantly different sources-marine shale source rock for the Santa Maria/Santa Barbara oil and lacustrine shale source rock for the Rozel Point oil. Both oils are believed to be of low thermal maturity. The presence of 2,5-dialkyl thiolanes in the Rozel Point oil (SCHMID et al., 1987; SiNNINGHE DAMSTÉ et al., 1987) indicates that biodegradation was not the major factor which resulted in the high asphaltene content of this oil, since dialkyl thiolanes are removed during biodegradation (FEDORAK et al., 1988).

Both oils show a similar trend in asphaltene/maltene organosulfur compositions. The asphaltene fractions have higher relative thiophene content, and the maltene fractions have higher relative sulfide content. Within the maltenes, the polar LC fraction has the highest relative sulfide content of any of the fractions, while the aromatic LC fraction exhibits the highest relative thiophene content; this is consistent with the findings of SINNINGHE DAMSTÉ et al., (1990). The aromatic fraction of the Rozel Point oil has a significantly higher proportion of thiophenes than that of the Santa Maria/Santa Barbara oil; however, it is difficult to assess the significance of this, given the limited size of our survey. Although extensive chemical investigations have been reported on the organosulfur composition of the volatile fractions of Rozel Point oil (SCHMID, 1986; SCHMID et al., 1987; SINNINGHE DAMSTÉ and DE LEEUW, 1987; SinNinghe DAMSTÉ et al., 1987, 1989b), our data provide the first total sulfide/thiophene/ sulfoxide analyses of the whole oil and various fractions. Additional measurements will be required to determine whether their organosulfur distributions are typical of sulfide-rich highsulfur oils.

\section{Autooxidation of Petroleum Organosulfur Compounds}

Most of the oils showed a low (less than $10 \%$ of the total sulfur) proportion of sulfoxide-containing components. We were therefore surprised that a series of light (Green River formation-sourced) low-sulfur oils from the Uinta Basin

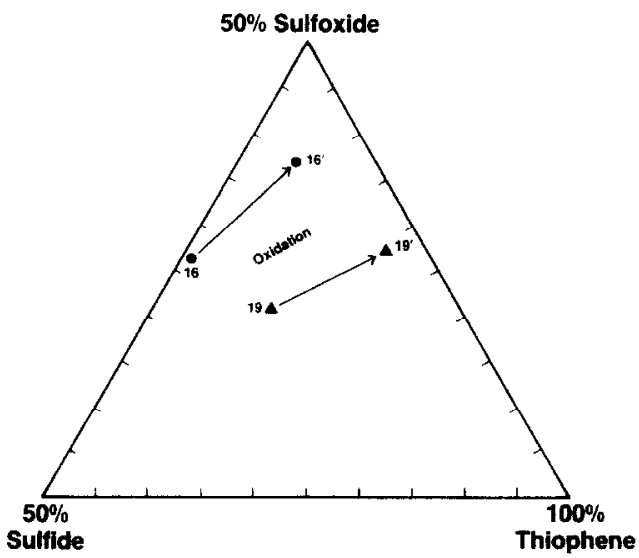

FIG. 8. Autooxidation of organosulfur species in Red Wash Field, Utah, crude oils shown by sulfur XANES analysis. Time-dependent oxidation of organosulfur species in oils during storage; oils No. 16 and 19 (see Table 2) were analyzed in June 1986 and again ( $16^{\prime}$ and $\left.19^{\prime}\right)$ in December 1987. 


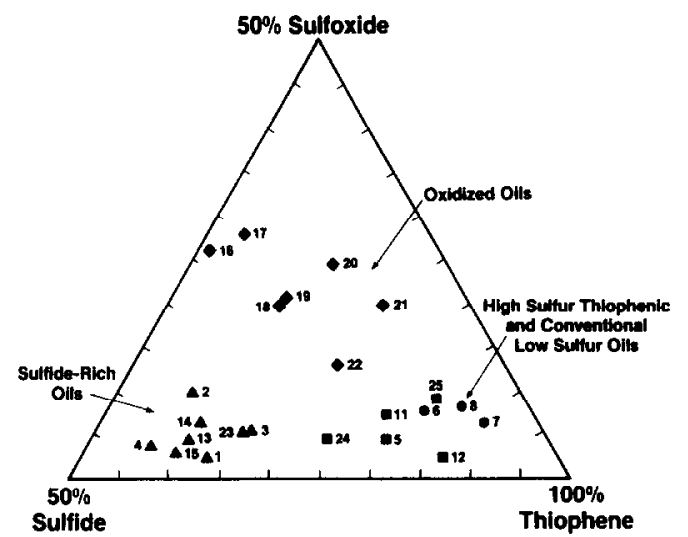

FIG. 9. Compilation of sulfur XANES petroleum analyses showing three tentative groupings: $(\Delta)$ sulfide-rich low and high sulfur oils: $(\bullet)$ Red Wash field (auto oxidized oils): ( $\square$ ) low sulfur conventional oils; and (๑) high sulfur thiophene-rich oils. Numbers by the data points are sample numbers listed in Table 2.

showed high proportions of sulfoxide moieties (Table 2). However, we found that when analyses were repeated following a year of storage without measures to exclude atmospheric oxygen, the proportion of sulfoxide increased significantly, as shown in Fig. 8. The rise in sulfoxide was accompanied by a proportional drop in sulfide content, suggesting that autooxidation has resulted in the conversion of some sulfide components to sulfoxides. This conclusion is reinforced by analysis of the asphaltene/maltene fractions for one of these oils (Sample No. 18, Table 2). The sulfoxide content in both of the fractions is higher than the sulfoxide content of the whole oil. This is presumably due to autooxidation of organosulfides in the crude during the asphaltene/ maltene fractionation procedure.

These findings support previous reports (OKUNO et al., 1967) of sulfoxide generation in crude oils during storage via autooxidation. However, we did not see analogous sulfoxide increases in other oils used which were stored for similar lengths of time under identical conditions. It appears, therefore, that only certain oils are readily susceptible to significant autooxidative degradation. This may be due to differences in the lability of the sulfide components, differences in the availability of organometallic compounds to act as oxidation catalysts, the presence of agents which inhibit autooxidation, or some combination of these factors.

\section{Whole Oil Sulfur XANES Anglyses}

Data from all of the whole oil samples in this study are summarized in Fig. 9. The data fall into three groups. The sulfide-rich oils include the high-sulfur Santa Maria/Santa Barbara and Rozel Point oils, and the low-sulfur highly immature petroleum or solid bitumen, gilsonite (HUNT, 1979), also referred to as uintaite. The Uinta Basin oils fall into a second group of oxidized (or at least oxidizable) oils with sulfoxide contents generally above $20 \%$ of total sulfur. The third group includes the thiophene-rich high-sulfur vils and conventional low-sulfur oils. Determination of the extent to which other petroleums conform to this grouping will be the goal of future studies.

\section{CONCLUSIONS}

- With appropriate normalization and self-absorption correction, sulfur XANES spectra can be used to determine the quantitative distribution of sulfur-containing compounds in petroleums and related materials. Although different compounds cannot be resolved, it is straightforward to distinguish between chemical classes. The exceptions are sulfides and polysulfides, which cannot be resolved.

- High-sulfur (greater than $1.0 \mathrm{wt} \%$ sulfur) petroleums show distinct sulfur compositional profiles identified as sulfiderich ( $>30 \%$ sulfide, $<65 \%$ thiophene) or thiophene-rich ( $<15 \%$ sulfide, $>75 \%$ thiophene). These compositional differences appear to be associated with clastic (sulfide-rich) or carbonate (thiophene-rich) sources, respectively.

- For petroleums derived from similar source rocks, higher thiophene content appears to be associated with greater thermal maturity. This holds for thermal maturities judged either by steroid biomarkers or by total sulfur content.

- The thiophene contents found for hydrous pyrolysis samples support the last point. Sulfur quantitation for the hydrous pyrolysis samples suggests that thiophene enrichment results from the selective loss or more labile sulfide and disulfide components during thermal maturation.

- Fractionation results in selective enrichment of sulfur compounds, in a manner consistent with the expected solubilities. Asphaltenes and aromatic maltenes are enriched in thiophenes. Polar maltenes are enriched in sulfide/disulfide compounds.

- Some petroleums show evidence for slow autooxidation of sulfide-like components to sulfoxides.

- Comparison of the whole oil sulfur composition profiles for all of the samples suggests that XANES will provide a useful method for distinguishing different petroleums. Further studies are necessary to confirm the generality of the observed compositional differences.

Acknowledgments-This work was supported in part by the donors to the Petroleum Research Fund and the Chevron Oil Field Research Company. We thank Dr. P. Frank for hclping to facilitate this study, Dr. B. Hedman, Prof. K. O. Hodgson, Prof. R. A. Scott and Dr. S. P. Cramer for spectra of some of the model compounds, Dr. S. R. Jacobson for thermal maturity data on the Red Wash Samples, D. K. Baskin for helpful discussions concerning the California Samples, and S. Wang, H. T. Tsang, and Dr. R. M. Fronko for assistance in data collection. We also thank W. L. Orr and J. S. Sinninghe Damsté for valuable criticisms of the manuscript.

Editorial handling: J. Rullkötter

\section{REFERENCES}

Aizenshtat Z., Stoler A., Cohen Y., and Nielsen H. (1983) The geochemical sulfur enrichment of recent organic matter by polysulfides in the Solar Lake. In Advances in Organic Geochemistry 1981 (eds. M. BJorøY et al.), pp. 279-288. J. Wiley \& Sons.

ANDERMANN G., FUJIWARA F., WORMAN J. J., and OLSON E. S. (1987) High resolution X-ray fluorescence spectroscopy. A potentially useful technique for chemical bonding studies in fossil fuels. Fuel 66, 932-934.

ayres M. G., Bilal M., Jones R. W., Slentz L. W., TaRTiR, M., 
and WILSON A. O. (1982) Hydrocarbon habitat in main producing areas, Saudi Arabia. AAPG Bull. 66, 1-9.

BART J. C. J. (1986) Near-edge X-ray absorption spectroscopy in catalysis. Adv. Catal. 34, 203-296.

BEAUMONT C., BOUTILIER R., MACKENZIE A. S., and RULlKÖTTER, J. (1985) Isomerization and aromatization of hydrocarbons and the paleothermometry and burial history of Alberta goreland basin. AAPG Bull. 69, 546-566.

BODUSZYNSKI M. M. (1987) Composition of heavy petroleums: I. Molecular weight, hydrogen deficiency, and heteroatom concentration as a function of atmospheric equivalent boiling point up to $1400^{\circ} \mathrm{F}\left(760^{\circ} \mathrm{C}\right)$. Energy Fuels 1, 2-11.

BORTZ, L. C. (1984) Heavy-oil deposit, Great Salt Lake, Utah. In Exploration for Heavy Crude Oil and Natural Bitumen, (ed. R. F. MEYER); AAPG Studies in Geology 25, pp. 555-563. Amer. Assoc. Petrol. Geol.

CASAGRANDE D. J. and NG L. (1979) Incorporation of elemental sulphur in coal as organic sulphur. Nature, 282, 598-599.

CaSagrande D. J., Idowu G., Friedman A., RICKert P., Siefert $\mathrm{K}$., and SCHLENZ D. (1979) $\mathrm{H}_{2} \mathrm{~S}$ incorporation in coal precursors: Origins of organic sulphur in coal. Nature 282, 599-600.

Clark D. T., and WiLSON R. (1984) Some aspects of the surface chemistry of coal, kerogen and bitumen as revealed by ESCA. Org. Geochem. 6, 455-461.

Clark D. T., Wilson R., and QuiRKE J. M. E. (1983) An evaluation of ESCA (electron spectroscopy for chemical applications) and other spectroscopic techniques in the surface and bulk characterization of kerogens, brown coal, and gilsonite. Chem. Geol. 39, 215-239.

Coleman H. J., Thompson C. J., Rall II. T., and Smith II. M. (1953) Thermal stability of high-sulfur crude oils. Ind. Eng. Chem. 45, 2706-2710.

CuRiale J. A. and OdermatT J. R. (1989) Short-term biomarker variability in the Monterey formation, Santa Maria basin. Org. Geochem. 14, 1-13.

Curiale J. A., CAMeron D., and Davis D. V. (1985) Biological marker distribution and significance in oils and rocks of the Monterey formation, California. Geochim. Cosmochim. Acta 49, 271288.

DE ROO J. and HODGSON G. W. (1978) Geochemical origin of organic sulfur compounds: thiophene derivatives from ethylbenzenes and sulfur. Chem. Geol. 22, 71-78.

DOuglas A. G. and MAIR B. J. (1965) Sulfur: Role in genesis of petroleum. Science 147, 499-501.

Eglinton T. I., Sinninghe Damsté J. S., Kohnen M. E. L., DE LeEUW J. W., LARTER S. R., and PATTENCE R. L. (1990) Analysis of maturity-related changes in organic sulfur composition of kerogens by flash pyrolysis-gas chromatography. In Geochemistry of Sulfur in Fossil Fuels (eds. W. L. ORR and C. M. WHITE); ACS Symposium Series 429, pp. 529-565. Amer. Chem. Soc.

FEDORAK, P. M., PAYZant J. D., MONTGOMERY D. S., and WeStLAKE D. W. S. (1988) Microbial degradation of n-alkyl tetrahydrothiophenes found in petroleum. Appl. Environ. Microbiology 54, 1243-1248.

Frank P., Hedman B., Carlson R. M. K., Tyson T. A., Roe A. L., and HoDGSON K. O. (1987) A large reservoir of sulfate and sulfonate residues within plasma cells from ascidia ceratodes, revealed by X-ray absorption near-edge structure spectroscopy. Biochem. 26, 4975-4979.

GeORGE G. N., and GoRBATY M. L. (1989) Sulfur K-edge X-ray absorption spectroscopy of petroleum asphaltenes and model compounds. J. Amer. Chem. Soc. 111, 3182-3186.

GOULON J., GOUlON-Ginet C., CORTES R., and DubOIS J. M. (1982) On experimental attenuation factors of the amplitude of the EXAFS uscillations in absorption, reflectivity and luminescence measurements. J. Phys. 43, 539-548.

GransCh J. A., and Posthuma J. (1974) On the origin of sulphur in crudes. In Advances in Organic Geochemistry 1973 (eds. B. TISSOT and F. BIENNER), pp. 727-739.

Hedman B., Frank P., PenNer-Hahn J. E., Roe A. L., Hodgson K. O., Carlson R. M. K., Brown G., Cerino J., and Hettel
R. (1986) Sulfur K-edge X-ray absorption studies using the 54 pole wiggler at SSRL in undulator mode. Nucl. Instr. Meth. Phys. Res., Sect. A. A246, 797-800.

Ho T. Y., Rogers M. A., Drushel H. V., and Koons C. B. (1974) Evolution of sulphur compounds in crude oils. AAPG Bull. $\mathbf{5 8 ,}$ 2338-2348.

huttman G. P., Huggins F. E., Shah N., Bhattachar yya D., Pugmire R. J., Davis B., Lytle F. W., and Greegor R. B. (1987) Investigation of the atomic and physical structure of organic and inorganic sulfur in coal. In Processing and Utilization of High Sulfur Coals, Proceedings of the 2nd International Conference (eds. Y. P. Chugh and R. D. CAUDLE), pp. 3-12. Elsevier.

Huffman G. P., Huggins F. E., Shah N., Bhattacharyya D., PugmiRe R. J., Davis B., LyTle F. W., and Greegor R. B. (1988) EXAFS investigation of organic sulfur in coal. Prep. Pap. Amer. Chem. Soc., Div. Fuel Chem. 33, 200-208.

Huffman G. P., Huggins F. E., Mitra S., Shah, N., Pugmire R. J., DAvis B., LYTLE F. W., and GREEGOR R. B. (1989) Investigation of the molecular structure of organic sulfur in coal by XAFS spectroscopy. Energy Fuels 3, 200-205.

Huffman G. P., Huggins F. E., Francis H. E., Mitra S., and SHAH N. (1990) Structural characterization of sulfur in bioprocessed coal. In Processing and Utilization of High Sulfur Coals (eds. R. MARKuszewsk. and T. D. WheELoCK); Coal Science and Technology 16, pp. 21-32.

HUGHES, W. B. (1984) Use of thiophenic organosulfur compounds in characterizing crude oils derived from carbonate versus siliciclastic sources. In Petroleum Geochemistry and Source Rock Potential of Carbonate Rocks (ed. J. G. PALACAS); AAPG Studies in Geology 18, pp. 181-196. Amer. Assoc. Petrol. Geol.

Hunt, J. M. (1979) Petroleum Geochemistry and Geology. W. H. Freeman.

Hunt, J. M., Stewaki F., and Dickey P. A. (1954) Origin of hydrocarbons of the Uinta basin, Utah. AAPG Bull. 38, 1671-1678.

Kohnen, M. E. L., SinNinghe Damste J. S., ten Haven H. L., and DE LEEUW J. W. (1989) Early incorporation of polysulphides in sedimentary organic matter. Nature 341, 640-641.

Kohnen M. E. L., Peakman T. M., Sinninghe Damsté J. S. and DE LEEUW J. W. (1990a) Identification and occurrence of novel $\mathrm{C}_{36}-\mathrm{C}_{54}$ 3,4-dialkylthiophenes with an unusual carbon skeleton in immature sediments. In Advances in Organic Geochemistry 1989 (ed. B. DuRAND); Org. Geochem. 16.

KoHNEn, M. E. L., Sinninghe Damsté J. S., Kock-VAN Dalen A. C., TEN Haven H. L., RUllkótter J., and DE LeEUW J. W. (1990b) Origin and diagenetic transformations of $C_{25}$ and $C_{30}$ highly branched isoprenoid sulfur compounds: Further evidence for the formation of organically bound sulfur during very early diagenesis. Geochim Cosmochim. Acta 54, 3053-3063.

KRAUSE M. O., and OLIVER J. H. (1979) Natural widths of atomic $\mathrm{K}$ and $\mathrm{L}$ levels, $\mathrm{K}_{\mathrm{u}} \mathrm{X}$-ray lines and several KLL Auger lines. $J$. Phys. Chem. Ref. Data 8, 329-338.

KROUSE H. R., Viau C. A., Eliuk L. S., Ueda A., and Halas S. (1988) Chemical and isotopic evidence of thermochemical sulfate reduction by light hydrocarbon gases in deep carbonate reservoirs. Nature 333, 415-419.

LEWAN M. D. (1985) Evaluation of petroleum generation by hydrous pyrolysis experimentation. Phil. Trans. Roy. Soc. London A315, 123-134.

lytle F. W., Greegor R. B., Sandstrom O. R., Marques E. C., WONG J., Spiro C. L., Huffman G. P., and Huggins F. E. (1984) Measurement of soft X-ray absorption spectra with a fluorescent ion chamber. Nucl. Instr. Meth. Phys. Rev. 226, 542-548.

MACKENZIE A. S. (1984) Applications of biological markers in petroleum geochemistry. In Advances in Petrological Geochemistry 1, (eds. S. J. BROOKS and D. WELTE), pp. 115-214. Academic Press.

Mackenzie A. S., Patience R. L., and Maxwell J. R. (1981) Molecular changes and the maturation of sedimentary organic matter. In Origin of Chemical Petrology Proceedings of the 3rd Annual Karcher Symposium (eds. G. ATKINSON and J. J. ZUCKERMAN), pp. 1-31. Pergamon. 
MAGOON L. B. and ISAACS C. M. (1983) Chemical characteristics of some crude oils from the Santa Maria basin, California, Calif. In Petroleum Generation and Occurrence in the Miocene Monterey Formation, California (eds. C. M. ISAACS and R. E. GARRISON), pp. 201-211. Soc. Econ. Paleontol. Mineral, Pacific Sect.

MajChrowiez B. B., Yperman J., Reggers G., Francols J. P., Gelan J, Martens H. J., Mullens J., and Van Poucke L. C. (1987) Characterization of organic sulfur functional groups in coal by means of temperature programmed reduction. Fuel Proc. Tech. $15,363-376$

MANGO F. D. (1983) The diagenesis of carbohydrates by hydrogen sulfide. Geochim. Cosmochim. Acta 47, 1433-1441.

MARTIN T. H., and HODGSON G. W. (1973) Geochemical origin of organic sulfur compounds: Reaction of phenylalanine with elemental sulfur. Chem. Geol. 12, 189-208.

MCKenzie D., MaCKenzie A. S., Maxwell J. R., and Sajgo C. (1983) Isomerization and aromatization of hydrocarbons in stretched sedimentary basins. Nature 301, 504-506.

McMaster W. H., KerR Del Grande N., Mallet J. M., and HUBELL J. H. (1969) Compilation of X-ray cross sections. UCRL50174, Sec. II, Rev, l. Natl. Tech. Inf. Serv., Springfield, VA.

Moldowan J. M., LEE C. Y., SUndararaman P., Salvatori T., AlAJBEG A., GJAKIC B., and DEMAISON G. J. (1989) Source correlation and maturity assessment of selected oils and rocks from the central Adriatic basin (Italy and Yugoslavia). Amer. Chem. Soc. Petrol. Div. Preprints, 34, 112-121.

Okuno I., Latham D. R., and Haines W. E. (1967) Separation of sulfoxides from petroleum fractions by cation exchange resin chromatography. Anal. Chem. 39(14), 1830-1833.

ORR W. L. (1974) Changes in sulfur content and isotopic ratios of sulfur during petroleum maturation-Study of Big Horn basin Paleozoic oils. AAPG Bull. 58, 2295-2318.

ORR W. L. (1986) Kerogen/asphaltene/sulfur relationships in sulfurrich Monterey oils. Org. Geochem. 10, 499-516.

ORR W. L. and SINNINGHE DAMSTE J. S. (1990) Geochemistry of sulfur in petroleum systems. In Geochemistry of Sulfur in Fossil Fuels (eds. W. L. ORR and C. M. WHITE); ACS Symposium Series 429 pp. 2-29. Amer. Chem. Soc.

Payzant J. D., MONTGOMery D. S., and Strausz P. P. (1983) Novel terpenoid sulfoxides and sulfides in petroleum. Tetrahedron Lett. 24, 651-654.

Payzant J. D., Montgomery D. S., and Strausz P. P. (1988) The identification of homologous series of benzo[b]thiophenes, thiophenes, thiolanes and thianes possessing a linear carbon framework in the pyrolysis of athabasca asphaltene. AOSTRA $J$. Res. 4, 117-131.

PAyzant J. D., MCINTYRe D. D., MOJelsky T. W., TORRES M., MONTGOMERY D. S., and STRAuSz O. P. (1989) The identification of homologous series of thiolanes and thianes possessing a linear carbon framework from petroleums and their interconversion under simulated geological conditions. Org. Geochem. 14, 461-473.

Peters K. E., Moldowan J. M., Driscoll A. R., and Demaison G. J. (1989) Origin of Beatrice oil by co-sourcing from Devonian and Middle Jurassic source rocks, Inner Moray Firth, U.K. AAPG Bull. 73, 454-471.

Peters K. E., Moldowan J. M. and Sundaraman P. (1990) Effects of hydrous pyrolysis in biomarker thermal maturity parameters: Monterey phosphatic and siliceous members. Org. Geochem. 15, 249-265.

PhilP R. P., Bakel A., Galvez-Sinibaldi A., and Lin L. H. (1988) A comparison of organosulphur compounds produced by pyrolysis of asphaltenes and those present in related crude oils and tar sands. In Advances in Organic Geochemistry, 1987 (eds. L. Novelul and L. Mattavelli), pp. 915-926. Pergamon.

Przewockı K., Malinski E., and SzafraneK J. (1984) Elemental sulfur reactions with toluene, bibenzyl, $Z$-stilbene and their geochemical significance. Chem. Geol. 47, 347-360.

Reynolds J. G., and BIGGS W. R. (1988) Application of size exclusion chromatography coupled with element-specific detection to the study of heavy crude oil and residua processing. Acc. Chem. Res. 21, 319-326.
RUIZ J.-M., CARDEN B. M., LENA L. J., VINCENT E.-J., and ESCAI I.ER J.-C. (1982) Determination of sulfur in asphalts by selective oxidation and photoelectron spectroscopy for chemical analysis. Anal. Chem. 54, 688-691.

SASSEN R. (1988) Geochemical and carbon isotopic studies of crude oil destruction, bitumen precipitation, and sulfate reduction in the decp Smackover formation. Org. Geochem. 12, 351-361.

SCHMID J. C. (1986) Marqueurs biologiques soufres dans les petroles. Ph.D thesis, Univ. Strausbourg, France.

SCHMID J. C., CONNAN J., and ALBRECHT P. (1987) Occurrence and geochemical significance of long-chain dialkylthiacyclopentanes. Nature 329, 54-56.

SEIFERT W. K. and MOLDOWAN J. M. (1986) Use of biological markers in petroleum exploration. Meth. Geochem. Geophys. 24, $261-290$.

SHI J. Y., Mackenzie A. S., AleXander R., Eglinton G., Gowar A. P., WOLFF G. A., and MAXWELL J. R. (1982) A biological marker investigation of petroleums and shales from the Shengli oilfield, The People's Republic of China. Chem. Geol. 35, 1-31.

SHou L., and MYHR M. B. (1988) Sulfur aromatic compounds as maturity parameters. In Advances in Organic Geochemistry, 1987 (eds. L. Novelli and L. MatTavelli), pp. 61-66. Pergamon.

SiNNINGHE DAMSTE J. S. (1988) Organically-bound sulphur in the geosphere: A molecular approach, $\mathrm{Ph} . \mathrm{D}$, Delf Univ.

SinNiNGHe DAMSTÉ J. S., and DE LEEUW J. W. (1987) The origin and fate of isoprenoid $\mathrm{C} 20$ and $\mathrm{C} 15$ sulphur compounds in sediments and oils. Intl. J. Env. Anal. Chem. 28, 1-19.

SinNinghe DAMSTE J. S., TEN HAVEN H. L., DE LEEUW J. W., and SCHENCK P. A. (1986) Organic geochemical studies of a Messinian evaporitic basin, northern Appenines (Italy). II. Isoprenoid and $n$ alkyl thiophenes and thiolanes. In Advances in Organic Geochemistry, 1985 (eds. D. LEYTHAEUSER and J. RULLKOTTER), pp. 791805. Pergamon.

Sinninghe Damste J. S., De Leeuw J. W. Kock-van Dalen A. C., DE ZeEuW M. A., DE LANGe F., RIJPSTRa W. I. C., and SCHENCK P. A. (1987) The occurence and identification of series of organic sulphur compounds in oils and sediment extracts. I. A study of Rozel Point oil (U.S.A.), Geochim. Cosmochim. Acta. 51, $2369-2391$.

Sinninghe Damste J. S., Kock-van Dalen A. C., De Leeuw J. W., and SCHENCK P. A. (1988a) Identification of homologous series of alkylated thiophenes, thiolanes, thianes and benzothiophenes present in pyrolysates of sulphur-rich kerogens. J. Chromatography 435, 435-452.

Sinninghe DAMSTE J. S., RupStRa W. I. C., DE LeEUW J. W., and SCHENCK P. A. (1988b) Origin of organic sulphur compounds and sulphur-containing high molecular weight substances in sediments and immature crude oils. Org. Geochem. 13, 593-606.

Sinninghe Damste J. S., Eglinton T. I., DE Leeuw J. W., and SCHENCK P. A. (1989a) Organic sulphur in macromolecular sedimentary organic matter: I. Structure and origin of sulphur-containing moieties in kerogen, asphaltenes and coal as revealed by flash pyrolysis. Geochim. Cosmochim. Acta. 53, 873-889.

SinNinghe Damste J. S., RiJPSTRA W. I. C., DE LeEUW J. W., and SCHENCK P. A. (1989b) The occurrence and identification of series of organic sulphur compounds in oils and sediment extracts: II. Their presence in samples form hypersaline and non-hypersaline palaeoenvironments and possible application as source, palaeoenvironmental and maturity indicators. Geochim. Cosmochim. Acta $53,1323-1341$.

Sinninghe Damsté J. S., Rupstra W. I. C., Kock-Van Dalen A. C., DE LEEUW J. W., and SCHENCK P. A. (1989c) Quenching of labile functionalized lipids by inorganic sulphur species: Evidence for the formation of sedimentary organic sulphur compounds at the early stages of diagenesis. Geochim. Cosmochim. Acta 53, 13431355.

SINNINGHE DAMSTE J. S., EGLINTON T. I., RIJPSTRA W. I. C., and DE LEEUW J. W. (1990) Characterization of organically bound sulfur in high-molecular-weight sedimentary organic matter using flash pyrolysis and Raney nickel desulfurization. In Geochemistry 
of Sulfur in Fossil Fuels (eds. W. L. ORR and C. M. WHITF); ACS Symposium Series 429. pp. 486-528. Amer. Chem. Soc.

Speight J. G. (1980) The Chemistry and Technology of Petroleum. Marcel Dekker.

Spiro C. L., Wong J., Lytle F. W., Greegor R. B., Maylotte D. H., and LAMSON S. H. (1984) X-Ray absorption spectroscopic investigation of sulfur sites in coal: Organic sulfur identification. Science 226, 48-50.

Stern E. A., Elam W. T., Bunker B. A., La K.-Q., and Heald S. M. (1982) Ion chambers for fluorescence and laboratory EXAFS detection. Nucl. Instr. Meth. 195, 345-346.

TANNENBAUM E., and AIZENSHTAT Z. (1985) Formation of immature asphalt from organic-rich carbonate rocks-1. Geochemical correlation. Org. Geochem. 8, 181-192.

THODE H. G., and MONSTER J. (1970) Sulfur isotope abundances and genetic relations of oil accumulations in the Middle East basin. Amer. Assoc. Petrol. Geol. Bull. 54, 627-637.

TissoT B. P. (1981) Generation of petroleum in carbonate rocks and shales of marine or lacustrine facies and its geochemical characteristics. In Petroleum Geology in China (ed. J. F. MASON), pp. 71-82. PennWell Books.
Tissot B. P., and Welte D. H. (1984) Petroleum Formation and Occurrence. Springer-Verlag.

TYSON T. A., RoE A. L., Frank P., Hodgson K. O., and Hedman B. (1989) Polarized experimental and theoretical K-cdge X-ray absorption studies of sulfate, chlorate, thiosulfate and dithionate anions. Phys. Rev. B 39, 6305-6315.

Valisolalao J., Perakis N., Chappe B., and Albrecht P. (1984) A novel sulfur containing $\mathrm{C} 35$ hopanoid in sediments. Tetrahedron Lett. 25, 1183-1186.

VALTTOV N. B. (1983) Experimental studies of the sulfur distributions in petroleum occurring in carbonate and terrigenous beds. Geokhimiia 3, 467-473.

Waldo G. S., and Penner-Hahn J. E. (1991) Normalization and self-absorption correction in XANES spectra (in prep.).

White C. M., Douglas L. J., SCHMidT C. E., and HaCKetT M. (1988) Formation of polycyclic thiophenes from reaction of selected polycyclic aromatic hydrocarbons with elemental sulfur and/or pyrite under mild conditions. Energy Fuels 2, 220-223.

WINICK H. and DoniaCH H. S., eds. (1980) Synchrotron Radiation Research. Plenum. 